\title{
The Cases of COVID-2019 and Changes at Autopsy
}

\author{
Olena Babkina ${ }^{1,2, ~ *, ~ V o l o d y m y r ~ Z o s i m e n k o ~}{ }^{2}$, Iana Ushko ${ }^{1}$, Olexsander Volobuev ${ }^{3}$ \\ ${ }^{1}$ Pathophysiology Department, Bogomolets National Medical University, Kyiv, Ukraine \\ ${ }^{2}$ Kiev Clinical Bureau of Forensic Medicine, Kyiv, Ukraine \\ ${ }^{3}$ Department of Forensic Medicine and Medical Law, Bogomolets National Medical University, Kyiv, Ukraine
}

Email address:

hpbsme@gmail.com (O. Babkina), zzosimsme@ukr.net (V. Zosimenko), ianaushko21@gmail.com (I. Ushko), volobuiev.alex (O. Volobuev)

${ }^{*}$ Corresponding author

To cite this article:

Olena Babkina, Volodymyr Zosimenko, Iana Ushko, Olexsander Volobuev. The Cases of COVID-2019 and Changes at Autopsy. American Journal of Internal Medicine. Vol. 8, No. 5, 2020, pp. 226-229. doi: 10.11648/j.ajim.20200805.16

Received: July 30, 2020; Accepted: August 12, 2020; Published: August 25, 2020

\begin{abstract}
The article demonstrates data on the identification and statistical analysis of cases of 2019-nCoV coronavirus infection and changes at autopsy. Exploratory data analysis was July 29, 2020. It has been demonstrated that despite the timely adoption of measures to prevent the spread in Ukraine of acute respiratory disease caused by the 2019-nCoV coronavirus, including the introduction of an emergency regime throughout Ukraine with restrictive measures, the number of infected people is constantly increasing, there is also the number of fatal consequences was increased, causing concern. As a result of the analysis, it was revealed that, unlike other countries of the world in Ukraine, the greatest number of infected people is observed in people aged 40-60 years, among which female persons prevail. The coronavirus COVID-19 affects not only the lungs but also other human organs. The necessity of compliance by the population with the recommendations of the Ministry of Health of Ukraine and World Health Organization (WHO) in Ukraine, as in the countries of the world for COVID-19, the implementation of quarantine standards to reduce cases of infection and deaths, was emphasized.
\end{abstract}

Keywords: Coronavirus 2019-nCoV, Infection, Mortality, Statistical Analysis, Changes at Autopsy

\section{Relevance}

On March 11, 2020, the World Health Organization identified the COVID-19 outbreak in the world like a pandemic, resulting in four possible country scenarios for COVID-19. Cases of pneumonia of unknown etiology were first detected in December 2019 in the city of Wuhan, Hubei Province, central China, which was reported by the Chinese authorities to the World Health Organization (WHO) on December 31, 2019. Subsequently, in 2020 (February 11), the disease was officially named SARSCoV-2 or 2019-nCoV (COVID-2019 coronavirus pneumonia). That is, a new virus has been discovered that causes the development of respiratory diseases in humans, namely acute COVID-19 respiratory disease and can be transmitted from person to person. Global COVID-19 studies show widespread dangerous infection, severe disease incidence, and high mortality rates in almost all countries of the world, despite unprecedented measures to prevent. The high spread in all countries of 201 coronavirus-induced acute respiratory disease V9 further concern among the population [1-10].

Currently, there are tools designed to monitor and develop an effective action plan for communicating effectively with the people, to help prepare and protect individuals and the public's health during the early response to COVID-19 [1113].

Thereby, continuous update and expansion of knowledge to the needs of society, a multi-disciplinary and entirely new approach to care for patients with COVID-19 are relevant now.

\section{The Purpose of the Work}

It was an analysis of the detection and consequences of cases of acute respiratory disease COVID-19 among the population in Ukraine and changes at autopsy. The research material was data published on the websites of the Ministry of Health of Ukraine, the Cabinet of Ministers of Ukraine, and international platforms. 


\section{Discussion}

Given the rapid spread of COVID-2019 worldwide, the severe disease incidence of $20-30 \%$ and the high mortality rate of ministers around the world taking quarantine measures worldwide and declaring a global emergency [14]. In 2020 (March 11), the WHO identified the COVID-19 pandemic outbreak in the world, addressing four possible scenarios in the countries for COVID-19. COVID-19 readiness and response guidelines were developed for each scenario. In addition, the guidelines for clinicians on "Clinical Management of Severe Acute Respiratory Infection (SARI) for COVID-19 Disease" were updated, and a guide on risk communication and public involvement plan for WHO COVID-19 Quarantine measures (some of which are listed below) were joined by Ukraine [15-18]. In Ukraine the coronavirus infection COVID-2019 was first recorded on March 3, 2020, in Bukovina in Chernivtsi, the first lethal event is March 13, 2020. As of July 29, 67597 persons were recorded infected with COVID-2019 in Ukraine, of whom 1650 died (with the exception of the occupied territory of Donbass and the annexed territory of Crimea). When assessing the number of infected and comparative characteristics as of July 29, 2020, we see that today the number of it in Ukraine is constantly increasing, and today has increased 67597 persons. The rapid increase of the infected (by 65\%) occurred on March 28-29.

Unfortunately, the number of deaths is increasing, which is $2.4 \%$ of the total number of infected people in Ukraine which is $1.5 \%$ less than the number of deaths in the world, where the figure reaches $3.9 \%$ of the full number of people infected. To date, the number of people recovering from COVID-2019 is $55.3 \%$ of the total number of people infected in Ukraine which is $6.6 \%$ less than the people number recovering from COVID-2019 in the world (Table 1).

Table 1. Comparative characteristics for COVID-2019 in the world and Ukraine as of July 29, 2020.

\begin{tabular}{lllll}
\hline & in the world & Ukraine \\
\hline infected & 16916860 & & 67597 & \\
have died & 663930 & $3,9 \%$ & 1650 & $2,4 \%$ \\
were cured & 10478020 & $61,9 \%$ & 37394 & $55,3 \%$ \\
the sick & 5774910 & $34,2 \%$ & 28553 & $42,3 \%$ \\
\hline
\end{tabular}

It should be noted that among COVID-19 infected in Ukraine the number of female persons prevails on men, on average by $5-7,4 \%$. Most infected people are most often aged $30-60$ years and make up 62\%, from other age groups (for example up to 20 years-about $4 \%, 21-29$ years-up to $11 \%$, $61-70$-about $15 \%$ ). The lowest number of infected persons is observed in persons after 80 years (up to $1 \%$ ). All of the deceased from COVID-19 recorded a positive laboratory test result for the pathogen. COVID-19 deaths have been reported in Ukraine, including $68 \%$ female and $32 \%$ male. The mortality rate of 40-60 years remains steadily high. The average duration from the origin of symptoms to the onset of death was 9 days, and from the moment of hospitalization to death-4 days. Among those who died from COVID-19, most individuals had a history of chronic diseases, the largest number of which were cardiovascular disease and diabetes, and cancer, kidney and lung disease, and obesity were also observed.

According to some reports, COVID-19 coronavirus affects not only the lungs but also other human organs (heart, liver, kidneys, circulatory and endocrine systems, and brain). The Cardiologist Joseph Brennan stressed that the COVID-19 has long-term effects on the body, and they can be irreversible [19]. In Thailand, the death of a medical examiner was recorded due to complications caused by the coronavirus. It is assumed that the expert did not contact other people, except for the deceased, during his work. At the same time, scientists note that the likelihood of transmission of infection from a dead person is unlikely since the virus after the death of the carrier lives in the body for a short time. It is believed that the lungs of people who have died from pneumonia caused by a new infection can be dangerous if not properly handled during dissection [20]. WHO urged caution when contacting the corpses of people who have died from coronavirus, since it is not fully understood how it can spread. According to scientists, forensic scientists and pathologists should wear a protective suit, glasses, gloves, and a medical mask. This will avoid contracting the coronavirus through contact with the deceased [21].

We performed an autopsy with a laboratory-confirmed diagnosis the COVID-19. In this case, the following changes were established (macroscopic):

The lungs fill the chest cavity upon opening. The $100 \mathrm{ml}$ of yellowish-pink fluid is determined in the pleural cavity on the left and right (signs of serous inflammation. A small amount of mural clear mucus is determined in the trachea and bronchi (signs of serous inflammation). The mucous membrane of the trachea and main bronchi is hyperemic, pinkish-red, thickened, with a dilated vascular network and light red petechial hemorrhage (Figure 1). The pulmonary pleura of both lungs is slightly swollen, with spotted and dark red petechial hemorrhage under it (Figure 2). The upper lobes of both lungs are doughy texture to the touch, on their surface the swelling and sunken of lung tissue are grinning through in places can be seen. The lung tissue at the autopsies is fullblooded, of a uniform dark red color, with a considerable amount of pale pink foamy fluid, which flows from the surface of the autopsies and during compression of the lung tissue. The lower lobes of both lungs and the middle lobe of the right lung are dense to the touch (Figure 3), airless, dark tissue on the section line, diffuse full-blooded, grayish-redbrown color, with areas of atelectasis. When checking for airiness of pieces of lung tissue-the lower lobes of both lungs and the middle lobe of the right lung sink in the water, which indicates a violation of gas exchange in these lobes. Pulmonary and bifurcated lymph nodes are enlarged, swollen, grayish-reddish-brown, homogeneous on autopsies.

The microscopic examination of the lungs and trachea revealed significant changes. In the lungs, the alveoli are mostly filled with serous-hemorrhagic exudate with groups of numerous desquamated alveolocytes and alveolar 
macrophages, among which giant multinucleated cells are identified. The interalveolar membranes are thickened due to edema and abundance lymphoid-macrophagal infiltration, sometimes sclerosed with the proliferation of interstitial cells. Vascular congestion with erythroaggregation, foci of erythrocytes accumulation in the perivascular stroma. Aggerate of lumpy eosinophilic masses of fibrin on the surface of the visceral pleura. The mucosal epithelium of the trachea is desquamated. Swelling of submucosal tissue with focal-loose lymphoid infiltration, foci of loose erythrocytes accumulation, sharp vascular congestion with erythroaggregation.

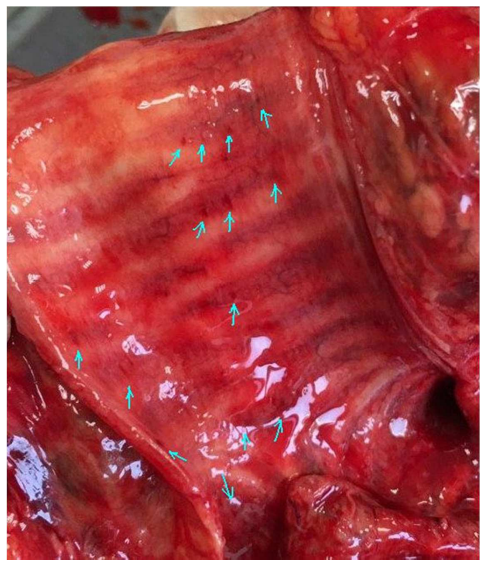

Figure 1. The petechial hemorrhage under the mucous membrane of the trache and bronchi.

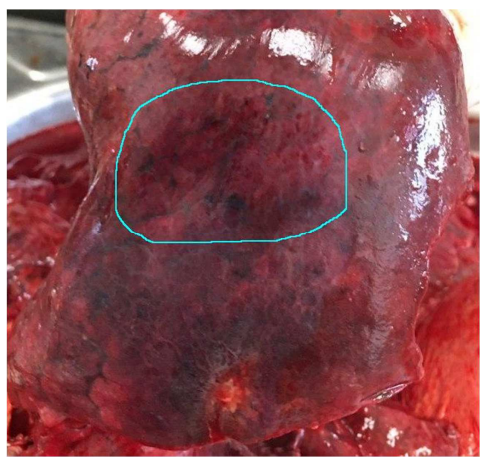

Figure 2. Spotted and dark red petechial hemorrhage under the pulmonary pleura.

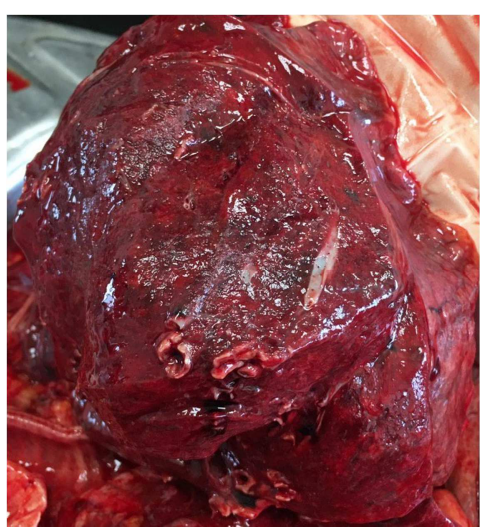

Figure 3. The induration of lung tissue of the lower lobe of the right lung on the section line.
That is, morphological signs of severe respiratory distress syndrome with the development of fibrosing alveolitis with widespread serous-hemorrhagic exudate, fibrinous pleurisy was revealed; catarrhal-desquamative tracheitis.

\section{Conclusions}

Thus, it can be argued that:

Ukraine had taken all steps to prevent the spread in Ukraine of acute respiratory disease caused by coronavirus 2019-nCoV.

It was introduced an emergency regime throughout Ukraine with restrictive measures, which is constantly increasing.

In Ukraine, a greater number of persons who was infected are observed in persons aged 20-40-60 years, among whom the dominance of female persons and their number is constantly increasing, there is a magnification in the number of fatalities, which is worrying.

Therefore, full compliance with the recommendations of the Ministry of Health care of Ukraine and WHO's response in Ukraine, as well as in the COVID-19 countries.

Characteristic morphological changes in the lungs and trachea we established by autopsy of a deceased with a laboratory-confirmed diagnosis of coronavirus. These include morphological signs of severe respiratory distress syndrome with the development of fibrosing alveolitis with widespread serous-hemorrhagic exudate, fibrinous pleurisy was revealed, catarrhal-desquamative tracheitis.

\section{References}

[1] https://www.worldometers.info/coronavirus/.

[2] Bernheim A, Mei X, Huang M, Yang Y, Fayad ZA, Zhang N, et al. Chest CT Findings in Coronavirus Disease-19 (COVID19): Relationship to Duration of Infection. Radiology. 2020; 200463. doi: 10.1148/radiol.2020200463.

[3] Bissett B, Hodgson C. Physiotherapy Management for COVID-19 in the Acute Hospital Setting: Recommendations to guide clinical practice. 2020.

[4] Li K, Wu J, Wu F, Guo D, Chen L, Fang Z, et al. The Clinical and Chest CT Features Associated with Severe and Critical COVID-19 Pneumonia. Invest Radiol. 2020; 1. doi: 10.1097/rli.0000000000000672.

[5] Pan Y, Guan H, Zhou S, Wang Y, Li Q, Zhu T, et al. Initial CT findings and temporal changes in patients with the novel coronavirus pneumonia (2019-nCoV): a study of 63 patients in Wuhan, China. Eur Radiol. 2020 Feb; 1-4. doi: 10.1007/s00330-020-06731-x.

[6] Shi H, Han X, Jiang N, Cao Y, Alwalid O, Gu J, et al. Radiological findings from 81 patients with COVID-19 pneumonia in Wuhan, China: a descriptive study. Lancet Infect Dis. 2020 Feb 24; 20 (4): P425-34. doi: 10.1016/S14733099(20)30086-4.

[7] Olena Babkina, IanaUshko and Olexsander Volobuev (2020) 'Assessment of Covid-2019 Cases in Ukraine and the World', International Journal of Current Advanced Research, 09 (05), pp. 22136-22138. DOI: http://dx.doi.org/10.24327/ijcar.2020.22138.4362. 
[8] Wang J, Wang BJ, Yang JC, Wang MY, Chen C, Luo GX, et al. Advances in the research of mechanism of pulmonary fibrosis induced by Corona Virus Disease 2019 and the corresponding therapeutic measures. Zhonghua shaoshang zazhi, Chinese $J$ Burn. 2020; 36: E006.

[9] Wu J, Wu X, Zeng W, Guo D, Fang Z, Chen L, et al. Chest CT Findings in Patients with Corona Virus Disease 2019 and its Relationship with Clinical Features. Invest Radiol. 2020; 1. doi: $10.1097 /$ rli.0000000000000670.

[10] ACSM Guidelines for Exercise Testing and Prescription 10th Nicolas Sepulveda Cisternas-Academia.edu. Available from: https://www.academia.edu/36843773/ACSM_Guidelines for Exercise_Testing_and_Prescription_10th (accessed 27 March 2020).

[11] Critical preparedness, readiness and response actions for COVID-19. Available from: https://apps.who.int/iris/handle/10665/331422.

[12] Clinical management of severe acute respiratory infection when novel coronavirus (nCoV) infection is suspected. Available from: https://www.who.int/publications/i/item/clinical-managementof-covid-19.

[13] Risk Communication and Community Engagement (RCCE)
Action Plan Guidance COVID-19 Preparedness and Response. Available from: https://www.who.int/publications/i/item/riskcommunication-and-community-engagement-(rcce)-actionplan-guidance.

[14] World health Organization. Coronavirus disease 2019 (COVID-19): Situation Report-39. 2020; 2. Available from: https://www.who.int/docs/defaultsource/coronaviruse/situation-reports/20200228-sitrep-39covid-19.pdf?sfvrsn=5bbf3e7d_4.

[15] https://moz.gov.ua/.

[16] https://index.minfin.com.ua/reference/coronavirus/ukraine/.

[17] https://www.who.int/ru/emergencies/diseases/novelcoronavirus-2019.

[18] http://w1.c1.rada.gov.ua/pls/zweb2/webproc4_1?pf3511=6840 2.

[19] https://www.rbc.ua/rus/styler/vrachi-sdelali-ugrozhayushcheezayavlenie-1587358502.html.

[20] https://argumenti.ru/world/2020/04/660570.

[21] https://apostrophe.ua/news/society/2020-04-14/zafiksirovannovyiy-sposob-peredachi-koronavirusa/194010. 